\title{
The influence of the ignition control on the performance of an aircraft radial piston engine
}

Aircraft piston engines are built with compromise on performance and safety. The desire to achieve the highest power-to-weight ratio leads to the search for solutions that optimize the combustion process. On the other hand, the need for maximum reliability leads to the simplification of the design at the costs of performance. An example of such a compromise is the ignition system of the ASz-62IR engine. In this engine there is a double magneto ignition system with a fixed ignition advance angle. As part of the modernisation of this engine, an electronically controlled dual ignition system was developed, which allows for optimum control of the ignition advance angle in terms of power. This article discusses the results of bench tests of the ASZ-62IR-16X engine with fixed ignition timing and variable timing control. Functional parameters and toxicity of exhaust gases were analyzed.

Key words: aircraft engine, ignition system, power, toxic emission

\section{Introduction}

The aviation industry is one of the fastest growing technology sectors [5, 6]. Lightweight and ultralight aircraft propelled by piston engines have an increasing share in this industry [5].

One of the most important requirements for these power units is to obtain as much power from the weight unit [6] Therefore, design solutions are being developed which allow to increase the power without the necessity to increase the weight of the engine. This is achieved by optimizing the combustion process [9], implementing turbocharging [4] or fuel and ignition advance angle control systems [1, 3]. Another very important factor is the safety and reliability of the design [1]. It is often in contradiction with the limitation of the engine mass: increased safety factors, introduction of redundant systems, etc. The engineers are faced with a dilemma: whether to introduce a new solution that increases engine power but at the same time may reduce the reliability of the structure (in the results of more elements, for example).

Currently, another factor is being introduced: ecology [6-8]. Solutions to reduce carbon dioxide emission [7] and toxic emission $[3,4]$ are being considered. This is achieved through changes in fuel type [3] and optimization of the combustion process [4]. The introduction of new electronically controlled fuel and ignition control systems also helps in this work [3].

This article presents the results of this type of work: the introduction of electronic ignition timing control system to an aircraft piston engine. The purpose of the analysis is to determine whether the introduction of this system will allow to achieve the objectives of increasing power and reducing engine emissions.

\section{Research description}

\subsection{Research objects}

The tests were conducted on the ASz-62IR-16X aviation engine manufactured by the WSK PZL Kalisz S.A. The engine is used in small and medium-sized cargo (Antonov AN-2) and agricultural (M18 Dromader) aircrafts. It is a four-stroke unit of nine cylinders in radial setup, air- cooled with electronic fuel injection control system and magneto ignition. Table 1 lists main parameters of the engine, and Fig. 1 presents the object of research in the test bed.

Table 1. ASz-62IR specification [2]

\begin{tabular}{|c|c|}
\hline Parameters & Values \\
\hline Engine diameter & $1380 \mathrm{~mm}$ \\
\hline Length & $1130 \mathrm{~mm}$ \\
\hline Dry engine mass & $567 \mathrm{~kg}( \pm 2 \%)$ \\
\hline Cylinder diameter & $155.5 \mathrm{~mm}$ \\
\hline Stroke & $174.5 \mathrm{~mm}$ \\
\hline Displacement & $29.911 \mathrm{dm}^{3}$ \\
\hline Compression rate & $6.4 \pm 0.1$ \\
\hline $\begin{array}{l}\text { Maximum power at } 2200 \mathrm{rpm} \\
\text { and } \mathrm{PK}=1050 \mathrm{mmHg}\end{array}$ & $1000 \mathrm{KM}(735 \mathrm{~kW})$ \\
\hline $\begin{array}{l}\text { Power rating at } 2100 \mathrm{rpm} \\
\text { and } \mathrm{PK}=900 \mathrm{mmHg}\end{array}$ & $820 \mathrm{KM}(603 \mathrm{~kW})$ \\
\hline Power rating at $\mathrm{h}=1500 \mathrm{~m}$ & $840 \mathrm{KM}(618 \mathrm{~kW})$ \\
\hline Power $(2030 \mathrm{rpm} \& \mathrm{PK}=830 \mathrm{mmHg})$ & $738 \mathrm{KM}(543 \mathrm{~kW})$ \\
\hline Power $(1930 \mathrm{rpm} \& \mathrm{PK}=745 \mathrm{mmHg})$ & $615 \mathrm{KM}(452 \mathrm{~kW})$ \\
\hline Power $(1770 \mathrm{rpm} \& \mathrm{PK}=665 \mathrm{mmHg})$ & $492 \mathrm{KM}(362 \mathrm{~kW})$ \\
\hline Average fuel consumption & $200 \mathrm{dm}^{3} / \mathrm{h}$ \\
\hline Maximum fuel consumption & $330 \mathrm{dm}^{3} / \mathrm{h}$ \\
\hline Weight to power ratio & $0.57 \mathrm{~kg} / \mathrm{KM}(0.42 \mathrm{~kg} / \mathrm{kW})$ \\
\hline Power to displacement ratio & $\begin{array}{c}33.43 \mathrm{KM} / \mathrm{dm}^{3} \\
\left(24.58 \mathrm{~kW} / \mathrm{dm}^{3}\right)\end{array}$ \\
\hline
\end{tabular}

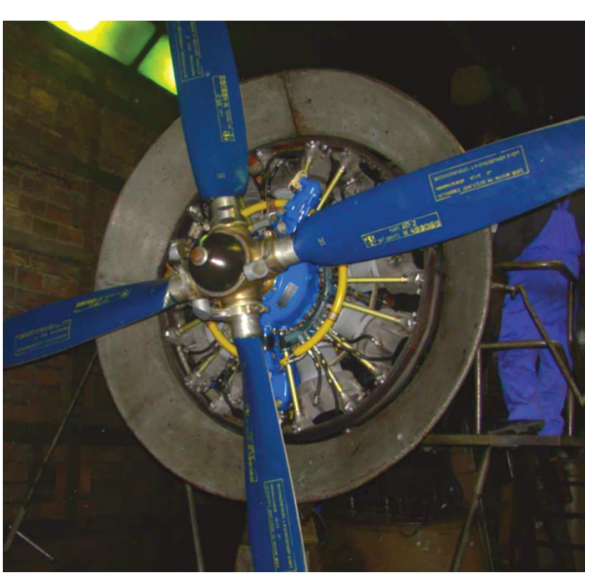

Fig. 1. ASz-62IR-16E engine in test bed 
The research was carried out on the ASz-62IR-16E engine equipped with electronic fuel injection system and its modification ASz-62IR-16X equipped additionally with electronically controlled ignition system. This system was designed within the project "Device for power supplying and controlling on-board and ground equipment" INNOLOT/ I/1/NCBR/2013 by the team of Lublin University of Technology and WSK "PZL Kalisz" S.A. The diagram of the system is shown in Fig. 2.

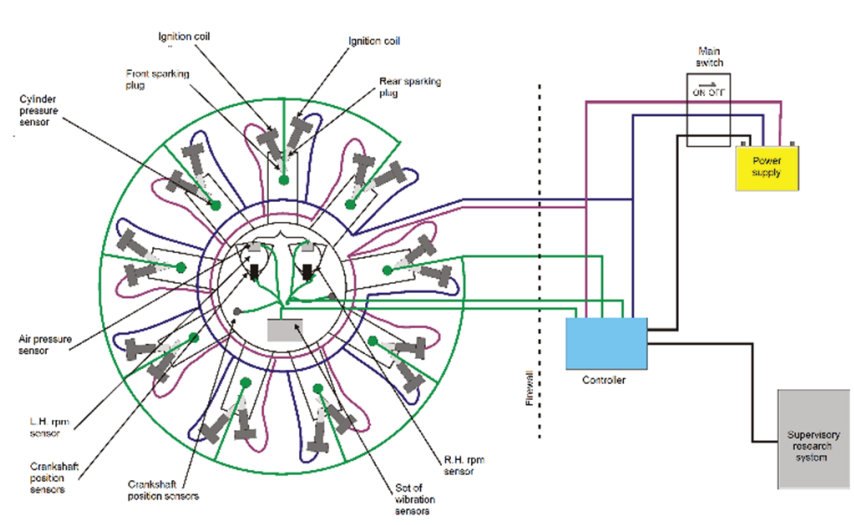

Fig. 2. Ignition system of ASz-62IR-16X engine

\subsection{Test stand}

The tests were carried out on a test stand located in the WSK „PZL Kalisz” S.A. - research and production stand at the engine manufacturer. The engine was braked by a propeller - Fig. 1. The torque measurement was performed on a reactive basis.

The combustion process was monitored by means of M3.5×0.6 optoelectronic sensors by OPTRAND, placed in the cylinder head. The sensors detected changes of the intensity of light transmitted by two adjacent optic fibers, one connected to a LED, and the other to a photo detector. The change of the intensity of light received by the photodiode was caused by the change of the intensity of light reflected by a steel membrane deformed by the in-cylinder pressure.

The rotational speed and crankshaft position were measured by means of a magnetically induced shaft position sensor. The sensors were located in a purpose-built adapter that enabled determining the TDC position of the first cylinder.

The following signals were measured during the experiment: pressure in 2 cylinders, pressure in inlet manifolds of cylinder 2 (by means of MPX250 sensors) and the position of the crankshaft. The measurement of all the signals were conducted by means of a digital to analogue converter DAQ-Pad 6070E (National Instruments) at the frequency of $30 \mathrm{kS} / \mathrm{s}$ per channel. The data were then processed by means of an original program created by the author.

Exhaust gas emissions were measured with the Pierburg Herman HG-400 analyser. Exhaust gas was taken from the exhaust manifold connecting cylinders 2 and 3 .

\subsection{Scope of research}

The aim of the research was to compare the performance of an engine operating with a constant ignition advance angle (ASz-62IR-6E engine) and with an ignition angle dependent on engine operating conditions (according to the calibration of the ASz-62IR-16X engine algorithm). Ignition advance angle for ASz-62IR-16E engine was $15^{\circ}$ before GMP for the front spark plug and $20^{\circ}$ before GMP for the rear spark plugs. The ignition advance angle for the ASz-62IR-16X engine varied between $10-21^{\circ}$ for the front spark plug and $15-26^{\circ}$ for the rear spark plug, depending on the rotational speed and intake manifold pressure.

Table 2. Parameters of the exhaust gas analyser HG-400

\begin{tabular}{|l|c|c|c|}
\hline Component & $\begin{array}{c}\text { Measurement } \\
\text { range }\end{array}$ & $\begin{array}{c}\text { Measurement } \\
\text { resolution }\end{array}$ & Measurement accuracy \\
\hline $\mathrm{CO}$ & $0 \ldots 10 \%$ vol & $\pm 0.01 \%$ vol. & $\begin{array}{c}<1.2 \% \text { vol. } \pm 0.06 \% \text { vol. } \\
\geq 1.2 \% \text { vol. } \pm 5 \%\end{array}$ \\
\hline $\mathrm{CO}_{2}$ & $0 \ldots 20 \%$ vol. & $\pm 0.1 \%$ vol. & $\begin{array}{c}<10 \% \text { vol. } \pm 0.5 \% \text { vol. } \\
\geq 10 \% \text { vol. } \pm 5 \%\end{array}$ \\
\hline $\mathrm{HC}$ & $\begin{array}{c}0 . .20000 \\
\text { ppm vol. }\end{array}$ & $\pm 1 \mathrm{ppm}$ vol. & $\begin{array}{c}<220 \mathrm{ppm} \text { vol. } \pm 11 \mathrm{ppm} \text { vol. } \\
\geq 220 \mathrm{ppm} \text { vol. } \pm 5 \%\end{array}$ \\
\hline $\mathrm{O}_{2}$ & $0 \ldots 22 \%$ vol. & $\pm 0.01 \%$ vol. & $\begin{array}{c}<2 \% \text { vol. } \pm 0.1 \% \mathrm{vol} . \\
\geq 2 \% \text { vol. } \pm 5 \%\end{array}$ \\
\hline $\mathrm{NO}_{\mathrm{x}}$ & $\begin{array}{c}0 . .5000 \\
\text { ppm vol. }\end{array}$ & $\pm 1 \mathrm{ppm}$ vol. & $\begin{array}{c}<500 \mathrm{ppm} \text { vol. } \pm 50 \mathrm{ppm} \text { vol. } \\
\geq 500 \mathrm{ppm} \text { vol. } \pm 10 \%\end{array}$ \\
\hline
\end{tabular}

The tests were carried out in steady state of engine operation at points corresponding to the acceptance tests of engine production. These points are in line with propeller characteristics and include: take-off power (2200 rpm), nominal power $(2100 \mathrm{rpm}), 90 \%$ of nominal power (2030 $\mathrm{rpm}), 75 \%$ of nominal power $(1910 \mathrm{rpm}), 60 \%$ of nominal power $(1770 \mathrm{rpm})$ and $50 \%$ of nominal power $(1670 \mathrm{rpm})$. At each point was measured:

1) The pressure in cylinder 2 in the following 500 cycles;

2) Torque;

3) Engine speed;

4) Exhaust gas composition.

Power was determined on the basis of torque and speed measurements and converted to normal conditions. Cylinder pressure measurements were analyzed and the mean indicated pressure and its standard deviation were determined for 500 consecutive cycles.

\section{Results}

The following figures show the results of research and analysis of comparison of engine performance with the constant ignition advance angle (ASz-62IR-16E engine) described in the diagrams as Constant and with the variable ignition advance angle (ASz-62IR-16X engine) described in the diagrams as Algorythm.

Figure 3 shows the reduced engine power at the particular measuring points on both ignition systems. It can be seen that the characteristics of the engine practically overlap. In order to show the level of changes, the percentage difference between the power obtained for an engine with a constant and variable ignition advance - Fig. 4. It can be seen that the determined differences do not exceed $2.5 \%$ and their average value is $0.7 \%$. Therefore, it can be considered negligible and resulting from the measurement spread. 


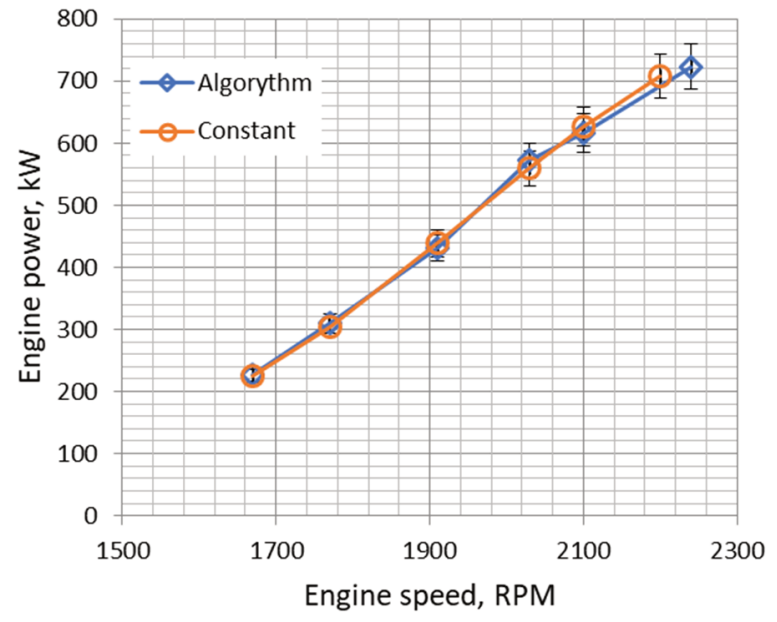

Fig. 3. Relationship between power and rotational speed for constant and variable ignition advance angle

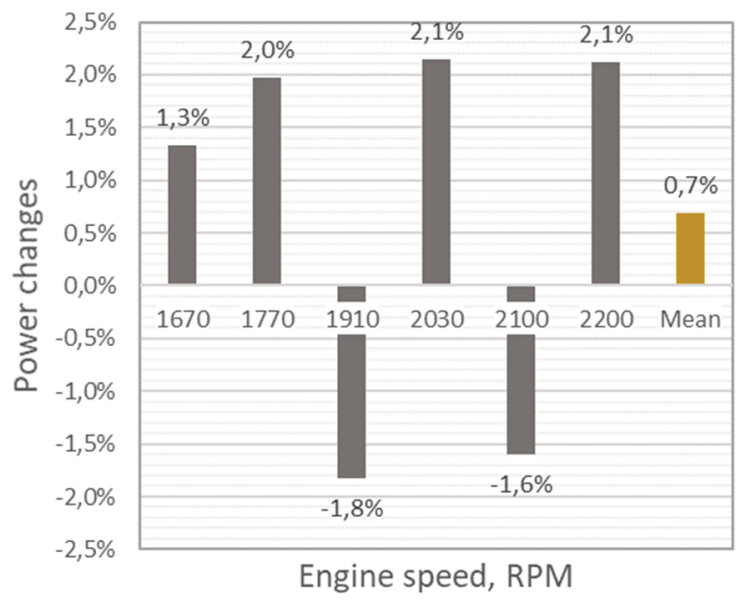

Fig. 4. Differences in reduced engine power between engines with constant and variable ignition advance angle

Figure 5 shows the mean indicated pressure from cylinder no. 2 of the engine at particular measuring points at both ignition systems. Here, too, the characteristics practically overlap. The differences - shown in Fig. 6 - are small and result mainly from the non-repeatability of the measurements.

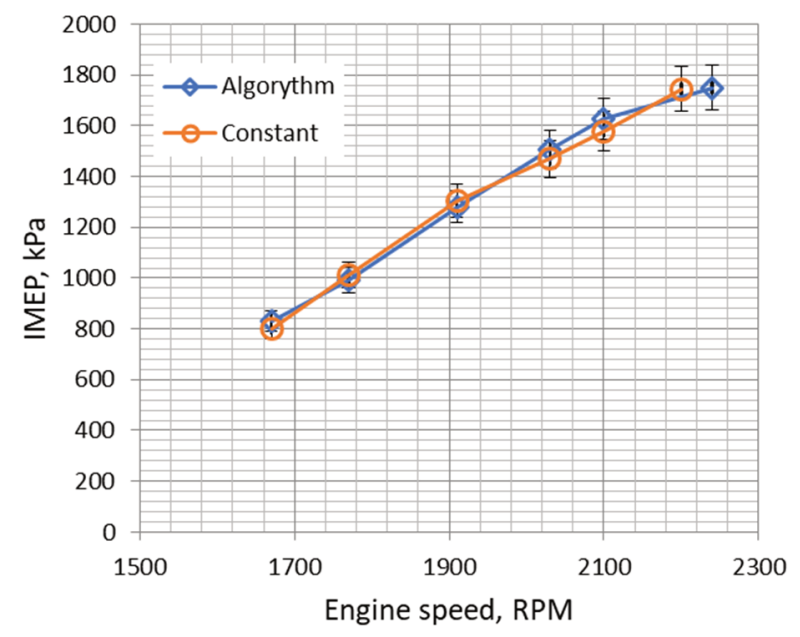

Fig. 5. Relationship between IMEP and rotational speed for constant and variable ignition advance angle

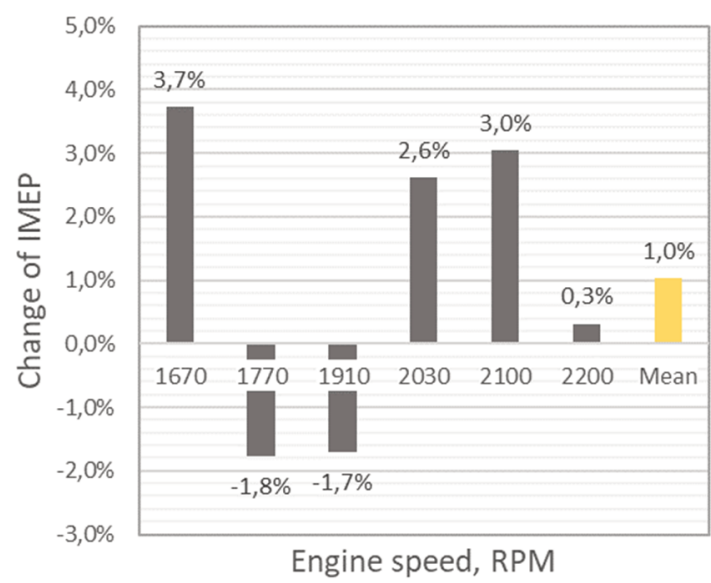

Fig. 6. Differences in IMEP power between engines with constant and variable ignition advance angle

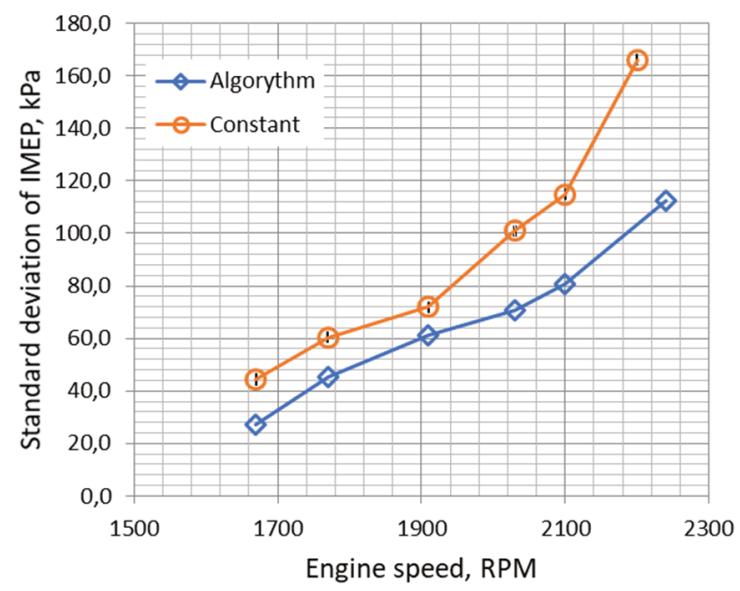

Fig. 7. Relationship between standard deviation of IMEP and rotational speed for constant and variable ignition advance angle

Significant differences were noted in the analysis of the standard deviation of the mean indicated pressure - Figs 7 and 8 . The use of electronically controlled ignition system allows to reduce the non-repeatability of the combustion process - lowering the standard deviation of the IMEP. The introduction of a variable ignition advance angle, better adapted to a specific point of work, allows to reduce the non-repeatability by more than $28 \%$ on average.

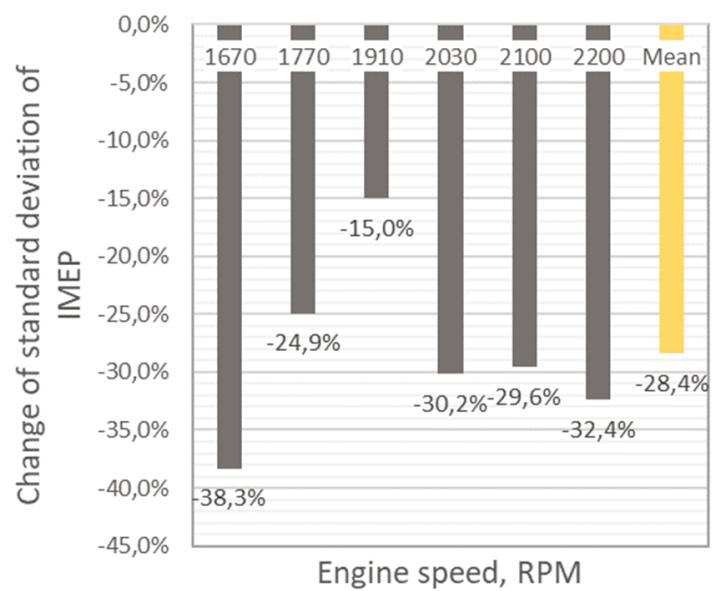

Fig. 8. Differences in standard deviation of IMEP power between engines with constant and variable ignition advance angle 
Figures 9 and 10 show carbon monoxide emissions. This engine is characterised by high $\mathrm{CO}$ emissions, especially at points of nominal power and take-off power. The emission value reaches $5.8 \%$ at nominal power and more than $10 \%$ at take-off power respectively. This is due to the regulation of the air-fuel mixture for these points. The mixture is very rich in this case (often exceeds lambda $<0.7$ ) as a result of the use of fuel for engine cooling. This is a characteristic solution for this type of engines. The use of a controlled ignition system results in a slight decrease in emissions at all measuring points. This decrease is on average $3.8 \%$ and means that ignition control has improved combustion quality.

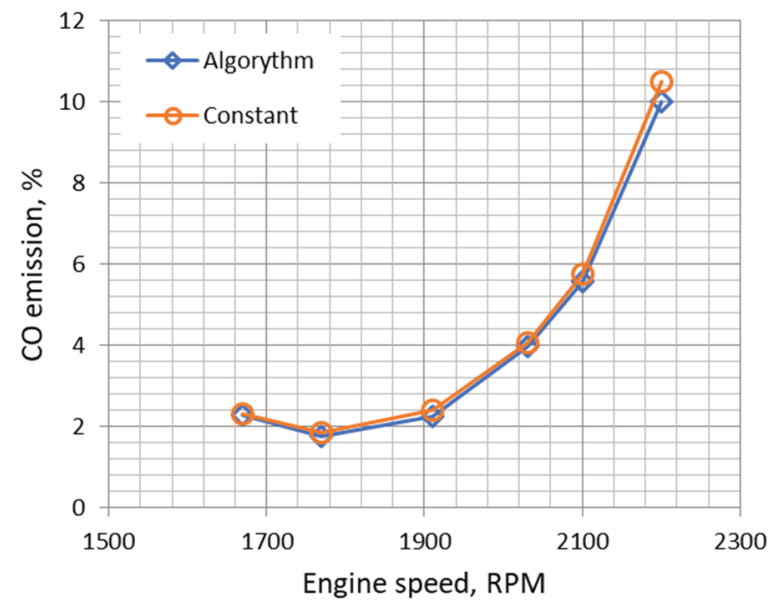

Fig. 9. Relationship between CO emission and rotational speed for constant and variable ignition advance angle

It is also noticeable in the level of emission of nonflammable HC hydrocarbons - Figs 11 and 12. One can also see high emission at points of nominal power and starting power resulting from engine cooling with fuel, reduced by $2.8 \%$ on average with improved ignition advance angle.

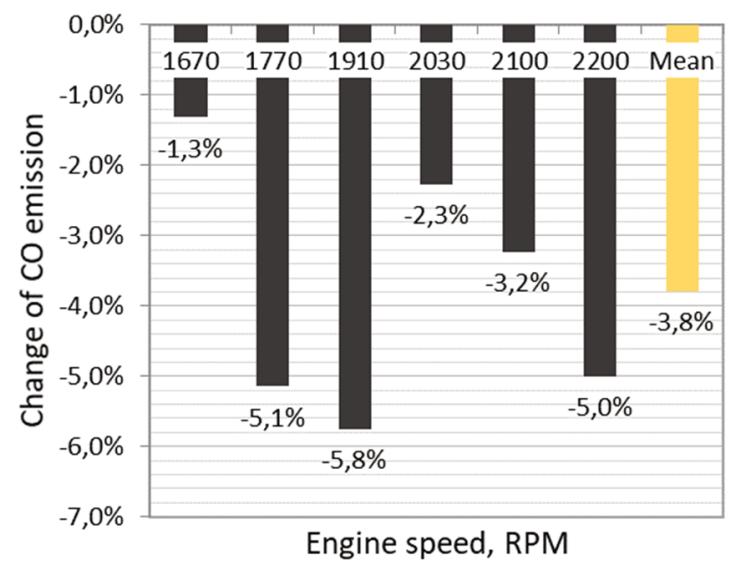

Fig. 10. Differences in CO emission power between engines with constant and variable ignition advance angle

This is also confirmed by the emission of carbon dioxide - Figs 13 and 14. In this case, the improvement of the combustion process results in an increase in $\mathrm{CO}_{2}$ emissions. This is due to the better oxidation of $\mathrm{HC}$ and $\mathrm{CO}$ (reduction of their emissions). With the introduction of ignition con- trol, an average increase in emissions of $1.9 \%$ was achieved.

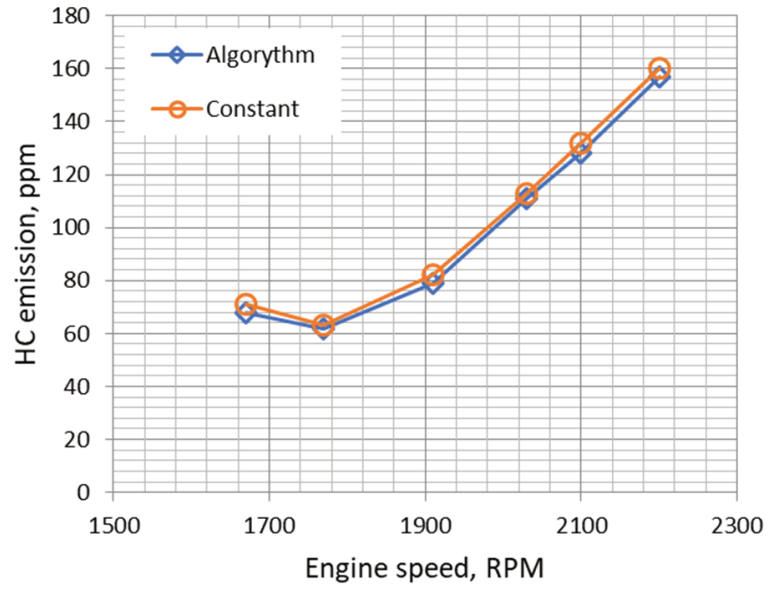

Fig. 11. Relationship between HC emission and rotational speed for constant and variable ignition advance angle

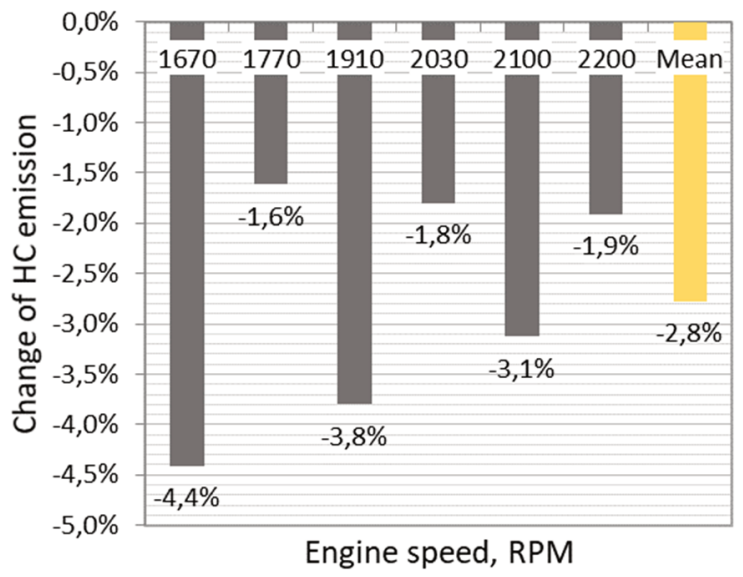

Fig. 12. Differences in HC emission power between engines with constant and variable ignition advance angle

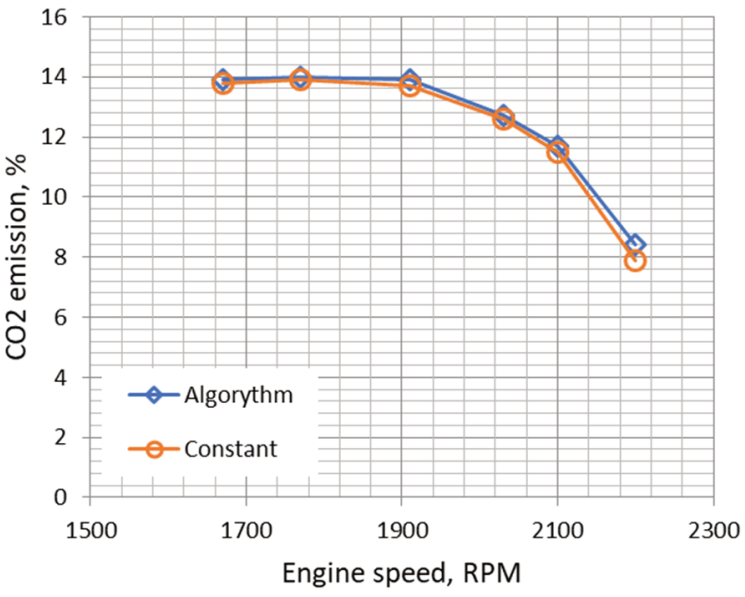

Fig. 13. Relationship between $\mathrm{CO}_{2}$ emission and rotational speed for constant and variable ignition advance angle

The improvement in combustion can also be seen in $\mathrm{NO}_{\mathrm{x}}$ emissions - Figs 15 and 16. At nominal power and $90 \%$ of nominal power, $\mathrm{NO}_{\mathrm{x}}$ emissions are the highest and 
exceed $1300 \mathrm{ppm}$. This is due to the power-optimal setting of both the composition of the mixture and the ignition advance angle. At the take-off power point, this value drops due to the lowering of the combustion temperature through significant enrichment of the mixture (Fig. 17).

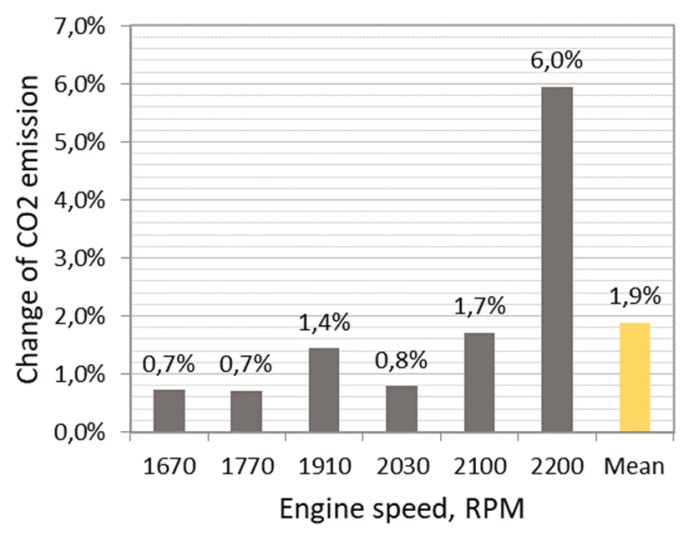

Fig. 14. Differences in $\mathrm{CO}_{2}$ emission power between engines with constant and variable ignition advance angle

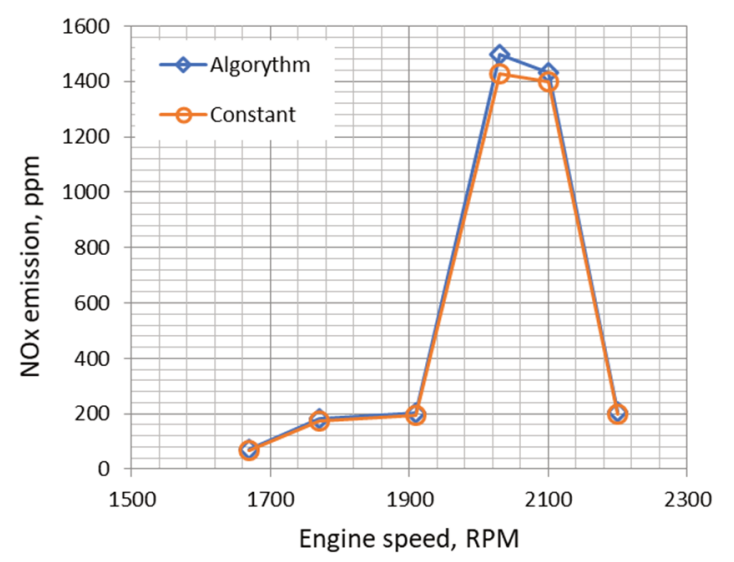

Fig. 15. Relationship between $\mathrm{NO}_{\mathrm{x}}$ emission and rotational speed for constant and variable ignition advance angle

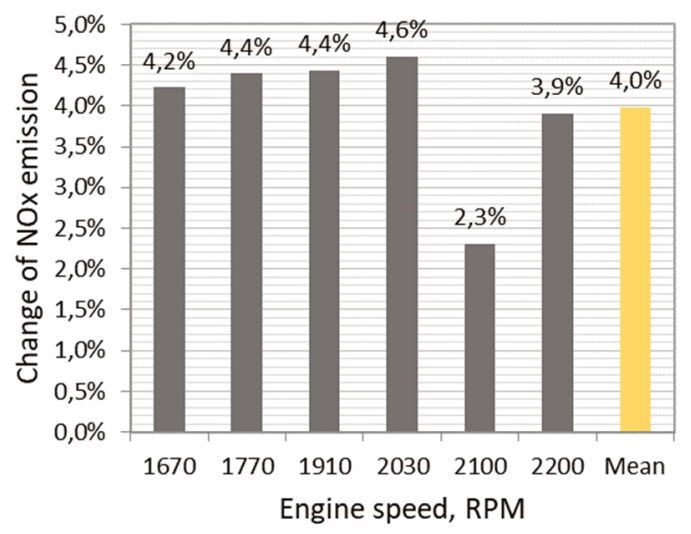

Fig. 16. Differences in $\mathrm{NO}_{\mathrm{x}}$ emission power between engines with constant and variable ignition advance angle
The introduction of ignition control improves the combustion process resulting in a reduction in $\mathrm{NO}_{\mathrm{x}}$ emissions. In the analyzed case, at each point the emission value was reduced and the average value decreased by $4.0 \%$.

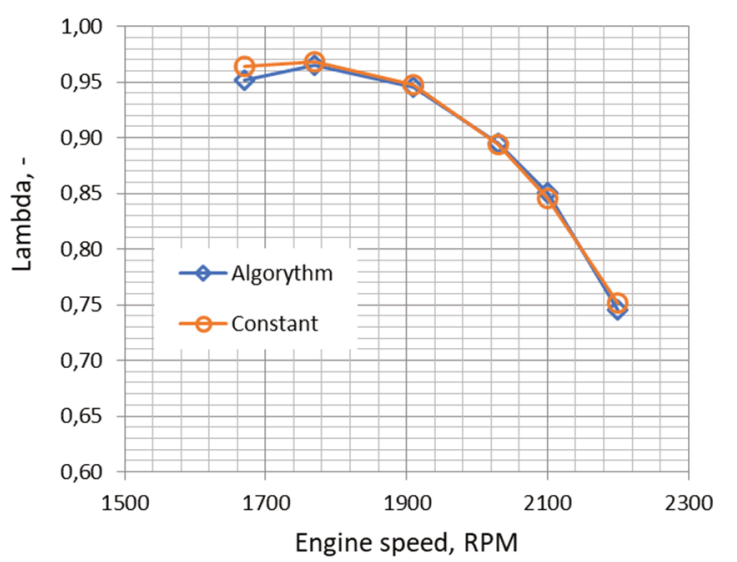

Fig. 17. Relationship between fuel ratio and rotational speed for constant and variable ignition advance angle

\section{Conclusions}

To summarize, it can be stated that for the tested engine design:

1. The use of ignition advance angle control with respect to engine speed and load has practically no effect on power output. This can be seen both in the obtained mean indicated pressures and reduced power. Therefore, the ignition advance angle in the case of its constant value has been correctly selected.

2. The introduction of ignition timing control has significantly contributed to the reduction of combustion nonrepeatability.

3. The introduction of ignition timing control has also improved the fuel oxidation process, which can be seen in the increase in $\mathrm{CO}_{2}$ in exhaust gases while reducing $\mathrm{CO}$ and $\mathrm{HC}$ emissions. However, the improvement in combustion resulted in an increase in $\mathrm{NO}_{\mathrm{x}}$ emissions.

Therefore, the use of an electronic control system for ignition timing mainly affects the stability of the combustion process, which will result in a reduction in vibrations of the engine. A much more important feature is the ability to easily adapt the ignition control to different types of fuels, which in the case of the previous system required mechanical adjustment.

\section{Acknowledgements}

This work was supported by the EU under the project "EPOCA Device for power supplying and controlling on-board and ground equipment" INNOLOT/I/1/NCBR/2013 within the framework the Operational Programme Smart Growth carried out by The National Centre for Research and Development.

\section{Nomenclature}

IMEP indicated mean effective pressure

$\mathrm{CO}$ carbon monoxide emission

$\mathrm{HC}$ non-flammable hydrocarbons emission
$\mathrm{NO}_{\mathrm{x}}$ nitrogen oxides emission

$\mathrm{CO}_{2}$ carbon dioxide emission 


\section{Bibliography}

[1] CAO, J., DING, S. Sensitivity analysis for safety design verification of general aviation reciprocating aircraft engine. Chinese Journal of Aeronautics. 2012, 25(5), 675-680. DOI:10.1016/S1000-9361(11)60433-0.

[2] CZARNIGOWSKI, J. Analysis of cycle-to-cycle variation and non-uniformity of energy production: Tests on individual cylinders of a radial piston engine. Applied Thermal Engineering. 2011, 31(10), 1816-1824, DOI:10.1016/j.appl thermaleng.2011.02.027.

[3] CZARNIGOWSKI, J., JAKLIŃSKI, P., WENDEKER, M Fuelling of aircraft radial piston engines by ES95 and 100LL gasoline, Fuel. 2010, 89(11), 3568-3578. DOI:10.1016/ j.fuel.2010.06.032.

[4] CZYŻ, Z., GRABOWSKI, Ł., PIETRYKOWSKI, K. et al. Measurement of flight parameters in terms of toxic emissions of the aircraft radial engine ASz62-IR, Measurement 2018, 113, 46-52. DOI:10.1016/j.measurement.2017.08.035.

[5] DALKILIC, S. Improving aircraft safety and reliability by aircraft maintenance technician training. Engineering Failure

Jacek Czarnigowski, DSc., DEng. - Faculty of Mechanical Engineering, Lublin University of Technology.

e-mail: j.czarnigowski@pollub.pl
Analysis. 2017, 82, 687-694. DOI:10.1016/j.engfailanal.2017. 06.008.

[6] DRAY, L. An analysis of the impact of aircraft lifecycles on aviation emissions mitigation policies. Journal of Air Transport Management. 2013, 28, 62-69. DOI:10.1016/j. jairtraman.2012.12.012.

[7] HASSAN, M., PFAENDER, H., MAVRIS, D. Probabilistic assessment of aviation $\mathrm{CO}_{2}$ emission targets. Transportation Research Part D: Transport and Environment. 2018, 63, 362-376. DOI:10.1016/j.trd.2018.06.006.

[8] KURNIAWAN, J. S., KHARDI, S. Comparison of methodologies estimating emissions of aircraft pollutants, environmental impact assessment around airports. Environmental Impact Assessment Review. 2011, 31(3), 240-252. DOI:10.1016/ j.eiar.2010.09.001.

[9] SUJATA, M., MADAN, M., RAGHAVENDRA, K. et al. Unraveling the cause of an aircraft accident. Engineering Failure Analysis. 2019, 97, 740-758. DOI: 10.1016/j.eng failanal.2019.01.065.

Piotr Jakliński, DSc., DEng. - Faculty of Mechanical Engineering, Lublin University of Technology.

e-mail: p.jaklinski@pollub.pl 